Вера Пешкова

\title{
ПОСТСОВЕТСКАЯ МИГРАЦИЯ И ДИАСПОРЫ ЧЕРЕЗ ПРИЗМУ ЛИМИНАЛЬНОСТИ
}

\begin{abstract}
Дается обзор некоторых современных исследований постсоветских диаспор из трех основных перспектив. Одна касается взаимодействия диаспор и родины на уровне государственной политики страны исхода по отношению к диаспорам. Другая охватывает влияние миграции на отправляющую и принимающие страны, а также на формирующиеся в результате нее диаспоральные сообщества. В отдельную тему выделяются механизмы формирования и практики постсоветских диаспор. Делается акцент на вынужденности постсоветской миграции, роли агентности, а также на микро-подходе в противовес доминирующему в литературе по постсоветским диаспорам макро-подходу. Это находит отражение и в методологической базе исследований миграции, поскольку часть из них основаны на анализе качественных интервью, включенном наблюдении и этнографических исследованиях. География работ охватывает русскоговорящую миграцию в Великобританию и Турцию, миграцию из Украины в Южную Европу и возвратную миграцию турокмесхетинцев в Грузию, трудовую миграцию из Азербайджана в Россию, миграцию между Молдовой и Европейским Союзом, и, наконец, постсоветскую еврейскую миграцию, в частности, между Россией, Израилем и Канадой. Особое внимание уделяется значению различных региональных, исторических, геополитических и межгосударственных контекстов, которые вписываются в транснациональную рамку, концептуализирующую миграцию как динамический и открытый процесс. Делается вывод, что для описания и понимания современных миграционных движений, в том числе формирования постсоветских диаспор, эффективно работает концепт лиминальности, раскрывающий переходный и процессуальный характер этих сложных процессов. Об этом свидетельствует опыт постсоветских мигрантов, которые часто находятся в состоянии двойственности, что отражается и на их самоидентификации, и на повседневных практиках («дефисная идентичность», «двойное возвращение», трансграничные практики и т.п.).
\end{abstract}

Ключевые слова: миграция, постсоветские диаспоры, лиминальность, транснационализм

DOI: $10.17323 / 727-0634-2018-16-4-701-710$

Вера Михайловна Пешкова - к.и.н., старший научный сотрудник, Федеральный научно-исследовательский социологический центр РАН, Москва, Россия. Электронная почта: pever@mail.ru 
Значение понятия диаспора, а также его применение в различных исторических и научных контекстах менялось. Тем не менее оно всегда было связано с осмыслением перемещения и расселения людей. Любое определение диаспоры включает три обязательные характеристики: причины расселения, поддержание связей со страной исхода в стране поселения и включение в принимающее общество (Faist 2010: 12). Изучение диаспор как научное направление формируется в 1980-е гг., в частности после выхода в 1986 г. коллективной монографии «Современные диаспоры в международной политике» (Sheffer 1986) и в 1991 г. специализированного канадско-американского журнал Diaspora.

Мощным импульсом новой волне исследований диаспор послужил распад Советского Союза, повлекший за собой глубокие геополитические и экономические трансформации не только в бывших социалистических странах, но и в мире в целом. Значительную долю первых исследований постсоветских диаспор составили работы, посвященные положению 25 млн людей, считающих Россию своей «этнической» родиной, но проживающих в 15 государствах-преемниках СССР (Kopnina 2005; Kosmarskaya 2011). В 1990-е гг. большинство постсоветских диаспор в научной литературе и в экспертном дискурсе идентифицировались как русские или имеющие русское происхождение, и изучались с точки зрения их новых социально-экономических статусов (Kolstø 1995, 1996). Позднее появляются работы, сосредоточенные и на других аспектах диаспор, например, на социальной мобилизации и проблемах постконфликтного периода (Zevelev 2001), миграции и моделях социальной адаптации (Pilkington 1998), идентичности (Laitin 1998).

По мнению ряда специалистов, исследования советской и постсоветской миграции группируются вокруг трех концептуальных дихотомий (Nikolko, Carment 2017: 1-11). Во-первых, это различие между добровольными и вынужденными мигрантами. Многие постсоветские диаспоры возникли не в следствие перемещения людей, а в результате образования новых национальных границ, и эта особенность их формирования повлияла как на государственную политику в отношении диаспор, так и на диаспоральные практики. Вторая дихотомия исходит из различия между «структурой» и «агентностью»: кто является действующим субъектом в миграционном процессе на постсоветском пространстве? Наконец, третья связана с тем, на каком уровне анализа (макро- или микро-) происходит изучение диаспор. В литературе по постсоветским диаспорам доминировал макроуровень, т.е. преимущественно анализ структурных политических и социальноэкономических процессов, вызывающих и сопровождающих миграцию (Pilkington 1998; Kolstø 1995).

В большинстве отечественных исследований осуществлялись попытки теоретического осмысления, насколько концепт диаспор соответствует актуальной постсоветской действительности (Тощенко, Чаптыкова 1996: 
36-37; Тишков 2000:46). Кроме того, российские исследователи обращались к изучению международных конфликтов применительно к диаспорам (Ким 2009), разных сторон деятельности диаспор, в том числе в российских регионах (Аствацатурова 2002). Значительный вклад в развитие отечественного изучения диаспор внес независимый научный журнал «Диаспоры». Он начал издаваться в 1999 г., и является первым и единственным русскоязычным журналом, посвященным экспатриированным сообществам, в первую очередь постсоветским диаспорам в современном мире.

$\mathrm{C}$ начала формирования специального направления изучения постсоветских диаспор социально-политические и экономические условия повсеместно трансформировались, что отразилось и на появлении новых подходов к изучению современных постсоветских диаспор. Из-за характера распада СССР, Югославии и Чехословакии в диаспорной политике постсоциалистических стран, выделается несколько особенностей: «молодость»; постепенный переход от оценки диаспорального населения как «предателей» до восприятия как важнейших агентов политики; ее оформление в качестве элемента внешней политики. Основными направлениями государственной диаспорной политики являются: помощь трудовым мигрантам в странах назначения, поддержка сохранения языка и культуры, разрешение двойного гражданства (Nikolko, Carment 2017: 12).

Для российской политики в отношении соотечественников за рубежом характерно поэтапное формирование. На него влияют политическая и экономическая ситуация в стране и в мире, направления и типы миграционных потоков, внешнеполитические интересы России и стран Евросоюза с государствами бывшего CCCP (Molodikova 2017). Российская диаспорная политика часто была реактивной (ibid: 146). В первой половине 2000-х гг. в ответ на демографический спад иммиграция стала одним из приоритетных направлений, а в 2007 г. поддержана созданием таможенного союза России, Белоруссии и Казахстана, предполагавшего свободное передвижение людей между странами-участниками. Из-за конфликтов в Грузии и Украине работа с соотечественниками за рубежом включена в стратегию внешней политики России (ibid: 157).

Другая перспектива изучения постсоветских диаспор охватывает вопросы влияния миграции и формирующихся диаспорных сообществ не только на собственно мигрантов и принимающую страну, но и на страну исхода. Например, рассматриваются последствия миграции для отправляющей страны на примере семей мигрантов, уехавших на сезонную работу из Азербайджана в Россию (Wistrand 2017). Хотя трудовая миграция позволяет семьям решать финансовые вопросы, в то же время она нарушает семейные, включая гендерные, роли. Складывается парадоксальная ситуация: женщины, чьи мужья работают в России, выполняют мужские и женские роли, но при этом традиционное положение мужчины в семье усиливается (ibid: 73-74). А что происходит, когда мигранты решают вернуться на родину? Следуя набирающей 
популярность в миграционных исследованиях транснациональной перспективе (Glick, Schiller et al. 1992; Levitt 2001; Faist 2008), возвращение концептуализируется как динамический и открытый процесс, предполагающий мобильность между принимающей страной и страной исхода (Flynn 2003; Brettel 2003; Cassarino 2004; Абашин 2017). Вернувшиеся мигранты адаптируются к жизни на родине с помощью создания своего бизнеса. Успешность возвращения определяется социальным, человеческим и финансовым капиталом, приобретенным за рубежом (Nikolko, Carment 2017:92).

Важным направлением исследований является вопрос адаптации репатриантов. Например, адаптация турок-месхетинцев, вернувшихся в Грузию из Средней Азии (Buchanan 2017). После распада СССР фактически за одну ночь месхетинцы оказались меньшинствами в государствах-преемниках. Их поселения отрезаны от других поселений Западной Грузии, закрыта чайная плантация, где большинство из них работало (ibid: 101-104). Ключевым механизмом, помогающим месхетинцам выходить из этого «двойного» возвращения с минимальными писхологическими потерями, стали ностальгические воспоминания о советском времени. Другим важным механизмом определения месхетинцами своего места в Западной Грузии, стало их участие вместе с грузинами в сезонной трудовой миграции в Турцию. Именно благодаря этому Грузия вернула свою роль родины предков, при этом став жизнеспособным вариантом будущего (ibid: 107).

Еще одно направление в современных исследованиях постсоветской миграции включает работы по изучению механизмов формирования конкретных постсоветских диаспор. Одним из эффективных способов понять, как сообщества мигрантов становятся диаспорами, является изучение персональной рефлексивности мигрантов. Например, украинские мигранты в Португалии отличаются высоким уровнем рефлексии, проявляющемся в появлении и распространении произведений художественной литературы и поэзии, посвященной опыту перемещения, ностальгии и адаптации к новым культурным условиям (Khanenko-Friesen 2017:47-63). Активность по производству, распределению и потреблению поэзии украинских мигрантов обозначается термином «поэтическая экономика», которая служит механизмом строительства украинских диаспорных общин в Португалии (ibid:57).

Важными факторами формирования диаспор являются исторические условия и политика принимающей стороны. На примере многочисленной постсоветской миграции русскоязычных евреев в Израиль, Анна Славина показывает конфликт между светским воспитанием и политикой Израиля по созданию национального государства на основе принципов иудаизма, что послужило причиной дальнейшей миграции части русскоязычных евреев из Израиля в Канаду (Slavina 2017). При этом, в отличие от старшего поколения, молодежь оказывается вовлеченной в три разные культуры. Для их миграционного опыта, а также самоидентификации решающее значение имеют школьные, соседские и семейные контексты. Отношения 
между поколениями выполняют разнообразные функции, в том числе сохранение родных языков и обычаев, создание историй, связывающих опыт молодежи с опытом их предков. В результате такого смешения культурных практик молодые люди в семьях еврейских мигрантов прошли сложный процесс согласования идентичностей и сформировали «дефисную» идентичность (Slavina 2017: 123).

Отдельно выделяются исследования русскоязычных мигрантов. Для понимания природы постсоветской русскоязычной диаспоры в Великобритании важно иметь в виду несколько факторов (Рechurina 2017:30-37). Boпервых, это сложный культурный характер постсоветской/российской миграции, который отражается в данных статистики, где нет единого русскоязычного сообщества, а есть группа, считающая русский язык основным; группа граждан России; группы, рожденные в разных республиках СССР, и даже те, кто считает себя гражданами СССР. Во-вторых, спорные данные о количестве постсоветских мигрантов, обычно обозначаемых общим словом «русские», усиливаются в медиа сведением всего русскоязычного населения до ограниченного числа категорий (например, «русские олигархи», или «русские куклы» в телешоу Russian Dolls). Определенную роль в строительстве русского диаспорного сообщества также играет рост социальной, культурной и политической активности российских государственных органов, мигрантских и культурных организаций (ibid: 38-40).

Знакомясь с русскоязычными диаспорными сообществами в Турции, мы получаем интересный материал для понимания роли региональных, исторических, геополитических и межгосударственных контекстов как в диаспорном строительстве, так и в отношении принимающей страны к внешним мигрантам (Aybak 2017). Русскоязычные диаспорные группы в Турции (как в миграции после гражданской войны, так и в постсоветской волне) оказались в состоянии «двусмысленности и неопределенности, где геополитические отличия создают предельные переживания в терминах отчужденности и интимных привязанностей к принимающему обществу через временную и "лиминальную стадию", что, в свою очередь, определяют вектор и особенности формирования русскоязычных диаспорных сообществ в Турции» (Aybak 2017: 129).

Представляется, что лиминальность является очень удачным термином не только для понимания состояния русскоязычных диаспорных сообществ в Турции, но и для описания и понимания современных миграционных процессов в большей части постсоветского пространства в целом. Согласно Виктору Тернеру, развившему вслед за Арнольдом ван Геннепом (1999) эту концепцию применительно к обрядам и ритуалам жизненного цикла, таким как рождение, свадьба, смерть - т.е. ритуалы изменения социального статуса - лиминальность является последовательным переходом от этапа разделения, через предельную фазу к включению и принятию нового состояния (Тернер 1983). Покидая свою страну, мигранты также входят 
в лиминальное состояние, но переход в принимающую среду не происходит немедленно и никогда не может быть завершен. Применяя терминологию Тернера, можно сказать, что многие современные мигранты из постсоветского пространства являются «лиминальными существами», находящимися в состоянии «ни здесь, ни там, ни то, ни се» (Тернер 1983: 168). Это отражается и на их самоидентификации (например, «дефисная идентичность»), и на повседневных практиках (например, состояние «двойного возвращения», трансграничные практики). Кроме того, лиминальным или переходным является, собственно, само формирование постсоветских диаспорных сообществ, а также политики отправляющих и принимающих государств по отношению к ним.

\section{Список источников}

Абашин С.Н. (2017) Возвращение домой и циркулярная мобильность: как кризисы меняют антропологический взгляд на миграцию. Этнографическое обозрение, (3): 5-15.

Аствацатурова М.А. (2002) Диаспоры в Российской Федераиии: формирование и управление (Северо-Кавказский регион). Ростов-на-Дону: СКАГС.

Геннеп А. (1999) Обряды перехода. Систематическое изучение обрядов. М: Восточная литература.

Ким А.С. (2009) Этнополитическое исследование современных диаспор (конфликтологический аспект). Автореф. дис. ...д-ра наук. Санкт-Петербург: Санкт-Петербургский государственный университет.

Тернер В. (1983) Символ и Ритуал. М.: Наука.

Тишков В.А. (2000) Исторический феномен диаспоры. Этнографическое обозрение, (2): $46-63$.

Тощенко Ж. Т., Чаптыкова Т.И. (1996) Диаспора как объект социологического исследования. Социологические исследования, (12): 33-42.

Aybak T. (2017) Russian-Speaking Diaspora in Turkey: The Geopolitics of Migration in the Black Sea Region. M. Nikolko, D. Carment (eds.) Post-Soviet Migration and Diasporas. From Global Perspectives to Everyday Practices. Basingstoke: Palgrave Macmillan: 127-143.

Brettel C. (2003) Return Migration, Transmigrants, and Transnationalism. C. Brettel (ed.) Anthropology and Migration: Essays on Transnationalism, Ethnicity, and Identity. Walnut Creek: AltaMira Press: 47-55.

Buchanan R. (2017) Transcending Return: The Experience of Making Home in the Republic of Georgia. M. Nikolko, D. Carment (eds.) Post-Soviet Migration and Diasporas. From Global Perspectives to Everyday Practices. Basingstoke: Palgrave Macmillan: 97-110.

Cassarino J. P. (2004) Theorising Return Migration: The Conceptual Approach to Return Migrants Revisited. International Journal on Multicultural Societies, 6 (2):253-279.

Faist T. (2008) Migrants as Transnational Development Agents: An Inquiry into the Newest Round of the Migration - Development Nexus. Population, Space and Place. 14 (1):21-42. 
Faist T. (2010) Diaspora and Transnationalism: What kind of Dance Partner. R. Baubeck, T. Faist (eds.) Diaspora and Transnationalism Concepts, Theories and Methods. Amsterdam: Amsterdam University Press: 9-34.

Flynn M. (2003) Returning Home? Approaches to Repatriation and Migrant Resettlement in Post-Soviet Russia. R. Münz, R. Ohliger (eds.) Diasporas and Ethnic Migrants: Germany, Israel and Post-Soviet Successor States in Comparative Perspective. London: Frank Cass Publishers: $173-187$.

Glick Schiller N., Basch L., Szanton Blanc C. (eds.) (1992) Towards a Transnational Perspective on Migration: Race, Class, Ethnicity, and Nationalism Reconsidered. New York: New York Academy of Sciences.

Khanenko-Friesen N. (2017) Migrant Self-Reflectivity and New Ukrainian Diaspora in Southern Europe: The Case of Portugal. M. Nikolko, D. Carment (eds.) Post-Soviet Migration and Diasporas. From Global Perspectives to Everyday Practices. Basingstoke: Palgrave Macmillan: $47-63$.

Kolstø P. (1995) Russians in the Former Soviet Republics. Bloomington: Indiana University Press.

Kolstø P. (1996) The New Russian Diaspora - an Identity of its Own? Possible Identity Trajectories for Russians in the former Soviet Republic. Ethnic and Racial Studies, 19 (3): 609-639.

Kopnina H. (2005) East to West Migration: Russian Migrants in Western Europe. Aldershot: Ashgate.

Kosmarskaya N. (2011) Russia and Post-Soviet 'Russian diaspora': Contrasting Visions, Conflicting Projects. Nationalism and Ethnic Politics, (17):54-74.

Laitin D. (1998) Identity in Formation: The Russian-Speaking Populations in the Near Abroad. Ithaca, NY: Cornell University Press.

Levitt P. (2001) The Transnational villager. Berkley: University of California Press.

Molodikova I. (2017) Russian Policy Towards Compatriots: Global, Regional and Local Approaches. M. Nikolko, D. Carment (eds.) Post-Soviet Migration and Diasporas. From Global Perspectives to Everyday Practices. Basingstoke: Palgrave Macmillan: 143-161.

Nikolko M., Carment D. (eds.) (2017) Post-Soviet Migration and Diasporas. From Global Perspectives to Everyday Practices. Basingstoke: Palgrave Macmillan.

Pechurina A. (2017) Post-Soviet Russian-Speaking Migration to the UK: The Discourses of Visibility and Accountability. M. Nikolko, D. Carment (eds.) Post-Soviet Migration and Diasporas. From Global Perspectives to Everyday Practices. Basingstoke: Palgrave Macmillan:29-45.

Pilkington H. (1998) Migration, Displacement, and Identity in Post-Soviet Russia. London: Routledge.

Sheffer G. (ed.) (1986) Modern Diasporas in International Politics. London: Croom Helm.

Slavina A. (2017) Jewish Russians, Russian Israelis and 'Jewski' Canadians: Youth and the Negotiation of Identity and Belonging. M. Nikolko, D. Carment (eds.) Post-Soviet Migration and Diasporas. From Global Perspectives to Everyday Practices. Basingstoke: Palgrave Macmillan: 111-125.

Wistrand J. S. (2017) Social Consequences of Seasonal Labour Migration: A Case Study from Rural Azerbaijan. M. Nikolko, D. Carment (eds.) Post-Soviet Migration and Diasporas. From Global Perspectives to Everyday Practices. Basingstoke: Palgrave Macmillan: 65-80.

Zevelev I. (2001) Russia and Its New Diasporas. Washington: US Institute of Peace Press. 


\section{POST-SOVIET MIGRATION AND DIASPORAS THROUGH THE LENS OF THE LIMINALITY}

The article gives an overview of some contemporary studies of post-soviet diasporas from three main perspectives. One relates to the interaction of the diasporas and the motherland at the state policy level of the country of origin in relation to the diasporas. The other covers the impact of migration on the sending and receiving countries, as well as on the diaspora communities emerging as a result. The mechanisms of the formation and practice of post-soviet diasporas are highlighted in a separate topic. The emphasis is on the emergence of many post-Soviet migrations, the role of agency, and also on the microapproach, as opposed to the macro-approach that dominates literature in the post-soviet Diaspora. This is reflected in the methodology based on a comprehensive analysis of quality interviews, included observation and ethnographic research. The geography of the researches covers Russian-speaking migration to Great Britain and Turkey, migration from Ukraine to Southern Europe and the return migration of Meskhetian Turks to Georgia, labor migration from Azerbaijan to Russia, migration between Moldova and the European Union, and finally post-Soviet Jewish migration, in particular, between Russia, Israel and Canada Particular attention is paid to the role of various regional, historical, geopolitical and interstate contexts, which are places into a transnational framework conceptualizing migration as a dynamic and open process presupposing permanent mobility between the host country and the country of origin. It is concluded that the concept of liminality, which reveals the transitional and procedural nature of these complex processes, is very effective in describing and understanding contemporary migration movements in general, including the formation of post-Soviet diasporas. This is clearly demonstrated by the experience of post-Soviet migrants, who are often in a state of duality, which is reflected in their self-identification and everyday practices (for example, 'hyphenated identity', 'double return', cross-border practices).

Key words: migration, post-Soviet Diasporas, liminality, transnationalism

DOI: $10.17323 / 727-0634-2018-16-4-701-710$

\section{References}

Abashin S.N. (2017) Vozvrashcheniye domoy i tsirkulyarnaya mobilnost: kak krizisy menyayut antropologicheskiy vzglyad na migratsiyu [Home Coming and Circular Mobility: How Crises Change the Anthropological View of Migration]. Etnograficheskoye obozreniye [Ethnographic Review], (3): 5-15.

Astvatsaturova M. A. (2002) Diaspory v Rossiyskoy Federatsii: formirovaniye i upravleniye (Severo-Kavkazskiy region) [Diasporas in the Russian Federation: Formation and Management (North Caucasus region)]. Rostov-na-Donu: SKAGS.

Vera Peshkova - PhD in History, Senior Research Fellow, Institute of Sociology of FCTAS, Moscow, Russian Federation. Email: pever@mail.ru 
Aybak T. (2017) Russian-Speaking Diaspora in Turkey: The Geopolitics of Migration in the Black Sea Region. M. Nikolko, D. Carment (eds.) Post-Soviet Migration and Diasporas. From Global Perspectives to Everyday Practices. Basingstoke: Palgrave Macmillan: 127-143.

Brettel C. (2003) Return Migration, Transmigrants, and Transnationalism. C. Brettel (ed.) Anthropology and Migration: Essays on Transnationalism, Ethnicity, and Identity. Walnut Creek: AltaMira Press: 47-55.

Buchanan R. (2017) Transcending Return: The Experience of Making Home in the Republic of Georgia. M. Nikolko, D. Carment (eds.) Post-Soviet Migration and Diasporas. From Global Perspectives to Everyday Practices. Basingstoke: Palgrave Macmillan:97-110.

Cassarino J.P. (2004) Theorising Return Migration: The Conceptual Approach to Return Migrants Revisited. International Journal on Multicultural Societies, 6 (2):253-279.

Faist T. (2010) Diaspora and Transnationalism: What kind of Dance Partner. R. Baubeck, T. Faist (eds.) Diaspora and Transnationalism Concepts, Theories and Methods. Amsterdam: Amsterdam University Press: 9-34.

Flynn M. (2003) Returning Home? Approaches to Repatriation and Migrant Resettlement in Post-Soviet Russia. R. Münz, R. Ohliger (eds.) Diasporas and Ethnic Migrants: Germany, Israel and Post-Soviet Successor States in Comparative Perspective. London: Frank Cass Publishers: $173-187$.

Gennep A. (1999) Obryadu perekhoda. Sistematicheskoe izuchenie obryadov [Rites of Transit. Systematic Study of Rituals]. Moscow: Vostochnaya literatura.

Glick Schiller N., Basch L., Szanton Blanc C. (eds.) (1992) Towards a Transnational Perspective on Migration: Race, Class, Ethnicity, and Nationalism Reconsidered. New York: New York Academy of Sciences.

Khanenko-Friesen N. (2017) Migrant Self-Reflectivity and New Ukrainian Diaspora in Southern Europe: The Case of Portugal. M. Nikolko, D. Carment (eds.) Post-Soviet Migration and Diasporas. From Global Perspectives to Everyday Practices. Basingstoke: Palgrave Macmillan: 47-63.

Kim A.C. (2009) Etnopoliticheskoe issledovanie sovremennyh diaspor (konfliktologicheski aspect) [Ethnopolitical Study of Modern Diasporas (Conflictological Aspect)]. Abstract of dissertation PhD. St. Petersburg: St. Petersburg University.

Kolstø P. (1995) Russians in the Former Soviet Republics. Bloomington: Indiana University Press.

Kolstø P. (1996) The New Russian Diaspora - an Identity of its Own? Possible Identity Trajectories for Russians in the former Soviet Republic. Ethnic and Racial Studies, 19 (3): 609-639. Kopnina H. (2005) East to West Migration: Russian Migrants in Western Europe. Aldershot: Ashgate.

Kosmarskaya N. (2011) Russia and Post-Soviet 'Russian diaspora': Contrasting Visions, Conflicting Projects. Nationalism and Ethnic Politics, (17): 54-74.

Laitin D. (1998) Identity in Formation: The Russian-Speaking Populations in the Near Abroad. Ithaca, NY: Cornell University Press.

Levitt P. (2001) The Transnational villager. Berkley: University of California Press.

Molodikova I. (2017) Russian Policy Towards Compatriots: Global, Regional and Local Approaches. M. Nikolko, D. Carment (eds.) Post-Soviet Migration and Diasporas. From Global Perspectives to Everyday Practices. Basingstoke: Palgrave Macmillan: 143-161.

Nikolko M., Carment D. (eds.) (2017) Post-Soviet Migration and Diasporas. From Global Perspectives to Everyday Practices. Basingstoke: Palgrave Macmillan.

Pechurina A. (2017) Post-Soviet Russian-Speaking Migration to the UK: The Discourses of Visibility and Accountability. M. Nikolko, D. Carment (eds.) Post-Soviet Migration and Diasporas. From Global Perspectives to Everyday Practices. Basingstoke: Palgrave Macmillan:29-45. Pilkington H. (1998) Migration, Displacement, and Identity in Post-Soviet Russia. London: Routledge.

Slavina A. (2017) Jewish Russians, Russian Israelis and 'Jewski' Canadians: Youth and the Negotiation of Identity and Belonging. M. Nikolko, D. Carment (eds.) Post-Soviet Migration and Diasporas. From Global Perspectives to Everyday Practices. Basingstoke: Palgrave Macmillan: 111-125. 
Tishkov V. A. (2000) Istoricheskiy fenomen diaspory [Historical Diaspora Phenomenon]. Etnograficheskoye obozreniye [Ethnographic Review], (2): 46-63.

Toshchenko Zh.T.. Chaptykova T. I. (1996) Diaspora kak obyekt sotsiologicheskogo issledovaniya [Diaspora as an Object of Sociological Research]. Sotsiologicheskiye issledovaniya [Sociological Studies], (12): 33-42.

Turner W. (1983) Simvol i ritual [Simbol and Ritual]. Moscow: Nauka.

Wistrand J. S. (2017) Social Consequences of Seasonal Labour Migration: A Case Study from Rural Azerbaijan. M. Nikolko, D. Carment (eds.) Post-Soviet Migration and Diasporas. From Global Perspectives to Everyday Practices. Basingstoke: Palgrave Macmillan: 65-80.

Zevelev I. (2001) Russia and Its New Diasporas. Washington: US Institute of Peace Press.

Leah Utyasheva

\section{RE-EXAMINING THE UZBEK NATION AND IDENTITY: THE NEXUS BETWEEN MIGRATION, ETHNICITY, LANGUAGE, AND BELONGING}

\section{Turaeva R. (2016) Migration and Identity in Central Asia: The Uzbek Experience. New York: Routledge, 219 p. ISBN: 978-1-138-91349-3}

Who are We? Who are the Others? What is the difference between Them and Us? These are the questions asked in Rano Turaeva's book Migration and Identity in Central Asia: The Uzbek Experience published by Routledge. Through the exploration of the inter-ethnic relations among internal Uzbek migrants in the capital city of Tashkent, the book discusses such issues as the elements of the Uzbek national identity, collective identification, and the influence of linguistic intricacies in the identification processes. The book undertakes an ambitions task of exploring the meaning of Uzbek ethnicity and identity (and different layers of it), analysing survival and networking strategies, identification processes, and de jure and de facto boundaries encountered by internal migrants from periphery to the capital. It provides a detailed analysis of the relations, communication, networking strategies, connections, dependencies and interdependencies that form survival techniques among internal migrants in this post-Soviet state. On the theoretical level, in discussing politics of belonging and identification among the groups living in Uzbekistan, the author examines collective identification/identity and making of the Other.

Each part of the book presents rich ethnographic material, based on the author's research among Khorezmians who moved to the capital city of Tashkent - a highly desirable place for all internal migrants in Uzbekistan. The book provides thick descriptions of everyday lives, survival strategies, prejudices and

Leah Utyasheva - Ph.D., Policy Director, the Centre for Pesticide Suicide Prevention, University of Edinburgh, UK. Email: lutyasheva@gmail.com 